\title{
Nörodejeneratif Hastalıklarda Oksidatif Stresin Rolü
}

\author{
The Role of Oxidative Stress in Neurodegenerative Diseases
}

${ }^{1}$ Kütahya Sağlık Bilimleri Üniversitesi, Simav Sağlık Hizmetleri Meslek Yüksekokulu, Kütahya, Türkiye.

${ }^{2}$ Eskișehir Osmangazi Üniversitesi, Tip Fakültesi, Dahili Tip Bilimleri Bölümü, Eskișehir, Türkiye

Correspondence:

Güllü KAYMAK

Kütahya Sağlık Bilimleri Üniversitesi Simav Sağllk Hizmetleri Meslek

Yüksekokulu, Kütahya, Türkiye

e-mail: gullu.kaymak@ksbu.edu.tr

\section{${ }^{1}$ Güllü Kaymak, ${ }^{2}$ Hasan Aydın}

\section{Özet}

Son dönemde oksidatif stresin nörodejeneratif hastalıklarda önemli rolü olduğuna dair bulgular artış göstermektedir. Oksidatif stres ve etkilerinin, kritik beyin bölgelerinde hasara neden olduğu; böylece nöronal sinyal iletişimini düzenleyen mekanizmalarda bozulma ile ortaya çıktığı düşünülmektedir. Klinik çalışmalarda, çeşitli nörodejeneratif hastalıklardan muzdarip hastalarda antioksidan enzim, lipid peroksidasyonu ve nitrik oksit düzeylerinde belirgin değişiklikler saptanmıștır. Mitokondri kompleksinde elektron akışı sırasında bazı elektronların zincirden kaçması ile reaktif oksijen radikalleri oluşmakta ve elektron transport zincir inhibisyonu ile mitokondrial işlev bozukluğu gelişmektedir. Mitokondrial işlev bozukluğu ve oksidatif hasar, hücre içi sinyal sisteminde, hücre içi kalsiyum dengesinde ve DNA yapısında değişiklikler oluşturarak sinir sisteminde kalıcı olumsuzluklara neden olabilir. Bu makalede, mevcut bilgiler gözden geçirilerek, klinik, hayvan ve hücre kültürü çalışmaları ile nörodejeneratif hastalıkların oksidatif denge ile ilişkisi analiz edilmiştir.

Anahtar kelimeler: Oksidatif stres; Parkinson; Alzheimer; ALS

\section{Abstract}

Recently, there is increasing evidence that oxidative stress has an important role in neurodegenerative diseases. Oxidative stress and its effects cause damage to critical brain regions; thus, it is thought to occur with the disruption in the mechanisms regulating neuronal signal communication. Clinical studies have found significant changes in antioxidant enzyme, lipid peroxidation, and nitric oxide levels in patients suffering from various neurodegenerative diseases. In the mitochondrial complex, reactive oxygen radicals are formed by the escape of some electrons from the chain during electron flow and mitochondrial dysfunction develops with electron transport chain inhibition. Mitochondrial dysfunction and oxidative damage may cause permanent adverse effects in the nervous system by creating changes in the intracellular signaling system, intracellular calcium balance and DNA structure. In this article, the current information is reviewed and the relationship of neurodegenerative diseases with oxidative balance is analyzed through clinical, animal and cell culture studies.

Keywords: Oxidative stress, Parkinson's disease; Alzheimer disease; ALS 


\section{Giriş}

Reaktif oksijen ve azot türlerinin (ROT/RAT) üretimi ve detoksifikasyonu arasındaki dengesizliğin neden olduğu oksidatif stres, beyin yaşlanmasında, nörodejeneratif hastalıklarda ve iskemi gibi diğer ilgili olumsuz koşullarda önemli bir rol oynar. Beyin oksidatif hasara karşı çeşitli nedenlerden dolayı çok hassas bir organdır. $\mathrm{Bu}$ nedenler; (i) diğer hücrelerle karşılaştırıldığında nöronların yüksek aerobik enerji döngüsü için oksidatif fosforilasyona olan bağımlılıkları; (ii) beyin vücut ağırlı̆̆ının sadece \%5'ini temsil etmesine rağmen, solunan oksijenin yaklaşık \%20'sini kullanarak yüksek oksijen konsantrasyonuna maruz kalması (fizyolojik koşullar altında, tüketilen oksijenin \%1-2'si ROT'a dönüştürülerek oksidatif strese yol açar ve bu yüzde yaşlı bireylerde dramatik olarak artar); (iii) beyinde yaşa bağlı olarak birikebilen ve oksidan oluşumu için güçlü bir katalizör olabilen demir gibi bazı metal iyonlarının fazlalığı; (iv) nöron zarlarının lipit peroksidasyonuna eğilimli çoklu doymamış yağ asitleri (PUFA) bakımından zenginliği; (v) hücresel süperoksitin ana üretim merkezi olan mitokondrilerin diğer organlara göre beyinde daha fazla bulunması; (vi) nöronların membran/stoplazmik hacim oranının yüksek olması ve akson morfolojisinin periferik hasara yatkınlığı; (vii) nöronların glutatyon üretme yeteneğinin olmaması ve nispeten zayif konsantrasyonlarda antioksidan içermesi, örneğin; karaciğerin yaklaşık \%10'u kadar; beynin detoksifikasyon kapasitesini sinırlandırır ve böylece oksidatif strese duyarlılığııı artırır (1-2).

Normal koşullarda serbest oksijen radikalleri enzimatik olan veya olmayan antioksidan mekanizmalarla uzaklaştırılırlar. Beyindeki major hücresel antioksidan ve redoks düzenleyicisi glutatyondur (GSH). Enzimatik mekanizmalar içerisinde yer alan süperoksit dismutaz (SOD), süperoksit radikallerini hidrojen peroksite (H2O2); katalaz ve glutatyon peroksidaz ise $\mathrm{H} 2 \mathrm{O} 2$ 'yi su ve oksijene dönüştürür (3). Serbest oksijen radikalleri yeterince elimine edilemezse membran ve organellerde yer alan lipit yapılarda, reseptör ve enzimlerde bulunan proteinlerde ve DNA'da oksidatif hücre hasarı meydana gelir. Böylece hücrelerin işlevleri olumsuz etkilenir ve nekrotik veya apoptotik hücre ölümüne neden olur. Malondialdehid başta olmak üzere lipit peroksidasyonunun son ürünleri tiobarbitürik asit reaktifleri (TBARS) yoluyla saptanırlar. TBARS ve protein karboniller, sirasiyla hücre lipit ve protein peroksidasyonunun doğrudan göstergesi olarak kabul edilirler (4). Oksidatif stres genel olarak, lipit peroksidasyonu, protein ve DNA hasarına ek olarak; iyon homeostazının bozulması, poli adenozin difosfat riboz polimeraz (PARP) aktivasyonu, ATP deplesyonu, reseptör inaktivasyonu, tamir edilemeyen fizyolojik hasarlar, mitokondriyal hasar veya kaspaz aktivasyonu yaparak hücrelerin hasarına/ölümüne yol açarak nörodejeneratif hastalıkların görülmesine neden olur (5).

Nörodejeneratif hastalıklar klinik olarak sinsi başlangicı ve kronik ilerlemesi ile karakterize edilir ve patolojik olarak ilerleyici işlev bozukluğu ve sıklıkla spesifik sinir sistemini etkileyen hücrelerin ölümü ile karakterizedir. Morfolojik olarak, nöronal kayıp, gliosis ile ve sıklıkla birçok nörodejeneratif bozukluğun temel özelliklerini (ayırt edici özelliklerini) temsil eden anormal hücre dışı ve hücre içi filamentöz birikiminin spesifik hücre tiplerinde acımasızca birikmesine yol açan proteinlerin yanlış katlanması ve birikmesi ile ilişkilidir. Birçok beyin nöronu oksidatif stres ile başa çıkabilirken, beyinde savunmasız olan belirli nöron popülasyonları vardır. Nöronal popülasyonlar arasındaki bu büyük çeşitlilik, tüm nöronların genomlarında aynı genetik kodu içermesine rağmen, her nöronal popülasyonun, genomun hangi bölümlerinin aktif ve hangi düzeylerde kendi benzersiz gen ekspresyon profiline sahip olduğunun güçlü bir göstergesidir. Nöronal yapıların ve fonksiyonların çeşitliliği nörobilim topluluğu tarafindan iyi belgelenirken, beyin nöronlarının yaşlanma sırasında veya nörodejeneratif hastalıkların bir sonucu olarak streslere ve olumsuz faktörlere farklı tepkiler vermesi üzerine çalışılması gereken bir konudur (6). Farklı nöronal popülasyonların stresli nörodejeneratif koşullara cevabında 
belirgin ama az çalışılmış bir fenomen olarak, Seçici Nöronal Kırılganlık (SNK) ortaya çıkar. SNK, merkezi sinir sistemindeki nöronal popülasyonların hücre hasarına veya ölüme neden olan ve nörodejenerasyona yol açan streslere karşı diferansiyel duyarlılığını ifade eder (7). Örneğin, entorhinal korteks, hipokampus CA1 bölgesi, frontal korteks ve amigdala'daki nöronlar, Alzheimer hastalığ 1 $(\mathrm{AH})$ ile ilişkili nörodejenerasyona en duyarlı nöron popülasyonlarıdır. Parkinson hastalığında $(\mathrm{PH}), \quad$ substantia nigra'nın dopaminerjik nöronları, hücre ölümüne uğrayan birincil nöronlardır. Amyotrofik lateral skleroz (ALS), öncelikle spinal motor nöronların dejenerasyonunun yanı sıra kortikal ve beyin sap1 nöronlarının dejenerasyonu ile karakterizedir. Spesifik beyin bölgelerinin çeşitli nörodejeneratif hastalıklarda oksidatif strese karşı farklı kırılganlıklar göstermesi, her hastalığın etiyolojisindeki özgüllüğün bir yansımasıdır (8).

\section{Alzheimer Hastalı̆̆}

Alzheimer, eşzamanlı davranışsal, duygusal, kişiler arası ve sosyal bozulma ile birlikte bellek, dil ve diğer bilişsel işlevlerde düşüş ile karakterizedir. $\mathrm{AH}$, en zorlu nörodejeneratif hastalıklardan biridir. Dünya çapında yaklaşık 50 milyon, Türkiye'de ise 300 bin kişiyi etkilemektedir ve görülme sıklığı 65 yaş ve üzerinde $\% 8$ 'e yükselmiştir. AH'nin birincil nedeni bilinmemekle birlikte, hiperfosforile edilmiş Tau düğümleri gibi bazı genetik mutasyonlar tanımlanmıştır (9). $\mathrm{AH}$ oluşumunda bazal apoptotik aktivite ve kalsiyuma bağlı potasyum kanallarındaki bozulmalara ek olarak, hastalığın patofizyolojisinde serbest radikaller de dahil olmak üzere ROT'un rolüne artan ilgi vardır. Lipit peroksidasyonu, AH'de nöronal dejenerasyonun baskın bir yoludur (10). Bu mekanizmada, hidroksil radikalleri, hidrojen atomlarını, membran fosfolipitlerinin çoklu doymamış yağ asidi yan zincirinden ayırır. Membran fosfolipitleri peroksi radikaline dönüştürülür ve adımları tekrar tekrar çoğaltabilir, böylece membran fosfolipitin iki tabakalı bileşimini tahrip edebilir ve özelliklerini değiştirebilir. Bu işlem, membran fonksiyonunun bozulmasıyla sonuçlanır, akışkanlığını azaltır ve kalsiyum gibi iyonların hücreye ve hücreden düzensiz geçişine izin vererek lizis potansiyeli yaratır. Tüm bu olaylar nihayetinde nörotransmitter sisteminin etkinliğini ve işlevini azaltır, böylece hastalığı başlatır (11). Çalışmalar, beynin frontal korteksinde yüksek lipit peroksidasyonu ile $\mathrm{AH}$ arasında bir ilişki olduğunu göstermiştir. Postmortem çalışmalarda beynin belirli bölgelerinde artmış lipit peroksidasyonu kaydedilmiştir. Demir, ferritin, alüminyum, cıva ve bakır gibi eser elementler, AH'nin nörodejenerasyonunda lipit peroksidasyonunu uyarır. Dopamin katabolizması aynı zamanda AH'de önemli bir serbest radikal üretimi kaynağıdır (12). AH için diğer olası mekanizmalar arasında glutamat hidroksi radikalinin üretimi ve birikmesi; ve hidrojen peroksitin dönüştürülmesinden elde edilen hidroksil radikalinin birikmesine yol açan süperoksit dismutaz (SOD) 'ın aşırı üretimi yer alabilir. Hücre içi serbest radikallerin birikmesinden ayr1 olarak, süperoksit dismutaz ve katalaz (CAT) gibi antioksidan enzimlerin aktivitelerindeki veya ekspresyonlarındaki değişiklikler, Alzheimer hastalarının hem merkezi sinir sisteminde hem de periferik dokularında tespit edilmiştir (13). H202, Alzheimer bozukluğunun ilerlemesinde nöritik plaktaki amiloid-b-proteinin birikmesine yanıt olarak üretilir. $\mathrm{AH}$, nöronal çökme ve oksidatif stres ile ilişkili neokorteks içinde amiloid- $\beta$-peptit $(A \beta)$ birikimi ile karakterizedir. $\mathrm{Bu}$ amiloidojenik yolakta, Amiloid öncü protein (APP), presenilin-1 (PS1) ve presenilin-2 (PS')'nin ailesel $\mathrm{AH}$ bağlantılı mutasyonları, hem serebral $\mathrm{A} \beta$ yükünü hem de $A \beta 1-42$ üretimini arttırır, böylece oksidatif stres tetiklenir (14). Ji ve ark. (2019), insan nöroblastoma (SH-SY5Y) hücrelerinin $A \beta$ ile muamelesi sonrasında hücre içi ROT miktarının ve MDA seviyesinin arttığııı ve SOD ile GSH-Px antioksidan enzim düzeyinin azaldığını bildirmiştir (15). Yine SH-SY5Y hücrelerinde A $\beta 1-42$ kaynakl1 sitotoksisitenin araştırıldığ 1 bir çalışmada, $A \beta$ ile oluşturulan Alzheimer grubundaki ROS miktarının kontrol grubuna göre on kat artış gösterdiği tespit edilmiştir (16). Zhang ve ark. (2019) tarafindan yapılan başka bir çalışmada, A 1 1-42'nin intrahipokampal enjeksiyonuyla sıçanlarda oluşturulmuş olan $\mathrm{AH}$ modelinde 
sıçan beyinlerinden elde edilen dokularda A $\beta$ 'nın SOD aktivitesini azalttığı ve MDA seviyesini ise artırdığı belirlenmiştir (17). Kantar Gök ve ark. (2018) tarafindan gerçekleştirilen çalışmada ise, A $\beta 1-42$ uygulanan hayvanlarda oksidatif stres belirteçleri olan 4-HNE ve TBARS seviyelerinin kontrol grubuna göre anlamlı bir şekilde arttığ tespit edilmiştir (18).

\section{Parkinson Hastalı̆̆}

Parkinson Hastalığı (PH), Alzheimer'dan sonraki en yaygın ikinci nörodejeneratif hastalıktır. Bu hastalığın görülme sıklığg 65 yaşın üzerindeki bireylerde \%3-4 olarak ortaya çıkmakta ve yaklaşık olarak dünya genelinde 10 milyon, Türkiye'de ise 150 bin insan bu hastalık ile yaşamaktadır. Geri dönüşü olmayan striatal nöron kayıpları ve bununla birlikte gelişen dopamin eksikliği sonucunda klinik semptomlar açığa çıkmaktadır (19). Günümüze kadar yapılmış olan çalışmaların 1şığında hastalığın ortaya çıkmasına hem çevresel ve hem de genetik faktörlerin etki ettiği görülmektedir. Her geçen gün bu nörodejeneratif hastalıkla yaşamak zorunda olan insanların sayılarındaki artış hastalığa neden olan risk faktörlerinin daha yoğun olarak araştırılmasının gerekliliğini ortaya koymaktadır.

Beynin substantia nigra'sındaki serbest radikal aracılı hasar ve ardından programlanmış hücre ölümü, PH'nın patogenezinin temelini oluşturabilir. Parkinson hastalarında serbest radikallerin oluşumunun kolay ancak uzaklaştırılmasının zor olduğu belirtilen çeşitli çalışmalar serbest radikallerin $\mathrm{PH}$ patogenezine dahil olmasını önermiştir (20). Ölüm sonrası parkinson hastalarının beyin dokularında yapılan biyokimyasal ölçümler, artmış serbest radikal oluşumunu göstermiştir. Serbest radikal hipotezi, dopamin nöronlarının nörokimyası ve beynin savunmasız bölgesi içindeki yerel ortamına dayanmaktadır. Dopaminin monoamin oksidaz A ve B ile oksidatif deaminasyonu, H2O2'nin enzimatik üretimine yol açar. Dopamin ve oksijen arasındaki enzimatik olmayan reaksiyonlar; süperoksit, hidrojen peroksit ve hidroksil radikallerinin üretimi ile sonuçlanabilir. Ayrıca dopaminin otomatik oksidasyonundan oluşan nöromelaninin ve onun otooksidasyonu toksik kinonlar ve ROT üretir (21).

PH aynı zamanda substantia nigra'daki seçici GSH kaybıyla da karakterizedir. Beynin diğer bölgelerinde bu kayıp gözlenmemektedir. GSH, hem bir redoks modülatör, hem de bir antioksidan olarak sinir sisteminde önemli bir rol oynamaktadır $\mathrm{Bu}$ bulgulardan yola çıkılarak bozulmuş GSH metabolizmasının PH'nın ortaya çıkış nedeni olduğu düşünülmektedir. Normal bireyler ile PH's1 olan bireylerde postmortem GSH/GSSG oran1 analizleri sonucunda $\mathrm{PH}$ olan bireylerde kontrol grubuna kiyasla bu oranın daha az olduğu ve azalmış GSH seviyesi saptanmıştır (22). Lipit peroksidasyonun olumsuz etkileri ve glutatyon miktarının beyinde azalmasının zamanla açığa çıkan PH'nin etiyolojisinde önemli rol teşkil ettiği düşünülmektedir (23).

Beynin substantia nigra bölgesi, H2O2'den hidroksil radikallerinin oluşumunu katalize eden demir iyonu bakımından zengindir. Demir birikiminin artmas1, serbest radikallerin üretimini arttırır ve glutatyon peroksidaz ve katalaz gibi serbest radikal süpürücü enzimlerin seviyelerini azaltır(24). Dexter ve ark., (1989) artan demir bağımlı lipit peroksidasyonunun Parkinson hastalarında hücre yıkımına katkıda bulunabileceğini bildirmiştir. Bu gözlemler, zararlı oksidatif olayların göstergesi olan spesifik bir kimyasal parmak izi önerisine yol açmıştır. Bunlar arasında yüksek seviyelerde kolesterol hidroperoksit, malondialdehit ve 4-HNE ve 8hidroksi-2-deoksiguanozin protein eklentileri bulunmaktadır (25). Bazı ailesel Parkinsonizm vakalarında $\alpha$-synüklein genindeki bir mutasyonun tanımlanmasi, bu vakalarda seçici dopaminerjik hücre ölümünün biyokimyasal mekanizmalarının anlaşılmasına yol açabilir (26). Nitrik oksit (NO) oluşumu da seçici dopaminerjik hücrelerin ölümüyle ilişkilendirilmiştir. NO oluşumu, bir formu belirli nöronlarda konsantre olan NO sentetaz (NOS) tarafindan katalize edilir. Hidroksil radikaline ayrışan ve lipit peroksidasyonuna, protein oksidasyonuna ve DNA hasarına yol açan peroksinitrit anyonunu vermek üzere süperoksit anyon radikali ile hızla reaksiyona girer. Nöronları çevreleyen nörogliyal 
hücrelerden NO üretimi nörodejeneratif hastalıkların patogenezine önemli ölçüde katkıda bulunur (27).

Oksidatif stres, nigral nöronal hücre ölümü için önemli bir faktördür.

Antioksidan mekanizmalardaki metabolik yetmezlik, teorik olarak lipit

peroksidasyonuna yol açan kimyasal süreçleri kolaylaştırabilir. Parkinson hastalarında yapılan çalışmalarda kontrol grubuna oranla plazma MDA düzeylerinde anlamlı artış gözlenmiştir (28). Yükselen lipit peroksidasyon oranlarının Parkinson hastalığ gelişme riskini artırabileceğini açıklamak için yapılan bu çalışmalarda en iyi PH belirtecinin MDA olduğu saptanmıştır. Bunun yanı sıra, MDA'nın PH süresi ile negatif, yaşlanma ile pozitif ilişki içinde olduğu gözlemlenmiştir. Sonuç olarak, oksidatif stresin PH gelişimine katk1 sağlayabileceği değerlendirilmiştir (29).

\section{Amyotrofik Lateral Skleroz (ALS)}

ALS, beyin sapında, korteksin üst motor nöronları ve omuriliğin alt motor nöronlarının ölümüyle karakterize ilerleyici ve ölümcül bir nörodejeneratif hastalıktır. Hastalığın nihai etkisi, genellikle semptom başlangıcından itibaren 3-5 y1l içinde ilerleyen kas güçsüzlüğ̈̈, atrofi ve solunum felci nedeniyle ölümdür. Her ne kadar ALS için insidans oran1 100.000'de 4-6 olsa da, altta yatan neden nispeten bilinmemektedir (24). Bununla birlikte, ALS'de motor nöronların dejenerasyonunun çeşitli nedenleri vardır. Bunlar: SOD1 mutasyonlar1, perikarya'da nörofilamentlerin anormal birikimi ve motor nöronların proksimal aksonları, protein, DNA ve fosfolipitlerin hasar, glutamat eksitotoksisitesi, bakır, apoptoz ve motor nöronların oldukça seçici hücre ölümü (30). Ek olarak, ALS'nin nedenleri olarak; oto bağışıklık, büyüme faktörleri, kronik viral enfeksiyon, alüminyum ve gıda toksinleri gibi çevresel toksinlere maruz kalma da araştırılmıştır. ALS'deki oksidatif stres teorisi, kümülatif hasarı ve hastalığın ilerlemesi nedeniyle özellikle önemlidir. ALS hastalığ 1 olan kişilerde şimdiye kadar insan SOD geninde 100 'den fazla mutasyon tanımlanmıştır. Transgenik fare çalışmaları yoluyla, bu mutasyonların SOD tarafindan toksik bir fonksiyon kazancına yol açtığı gösterilmiştir. $\mathrm{Bu}$ işlev kazanımının doğası geniş ölçüdde tartışılmaktadır ve iki ana teori vardır: biri toksisitenin yanlış katlanmış birleștirilmiş SOD formlarından kaynaklandığını gösterirken, diğeri SOD'un pro-oksidan protein üreten bir ROT olmasını öneriyor. ROT süperoksitini detoksifiye eden bir enzim olan SOD, mutasyonlarla proteini bir antioksidandan oksidatif strese neden olabilecek bir pro-oksidana dönüştürebilir. Anormal özelliklere sahip mutant SOD1'in peroksinitrit ve Fenton benzeri reaksiyonlar ürettiği gösterilmiştir (31). Bir G93A Sod1 transgenik fare modeli kullanan Liu ve ark. (2002) omuriliklerde serbest oksijen radikallerinin artan üretiminin ALS benzeri hastalık başlangıcı ve ilerlemesi ile ilişkili olduğunu göstermiştir. Protein karbonilleri ve protein nitrasyonu gibi oksidasyon belirteçlerinin hem insan ALS hastalarında hem de ALS benzeri transgenik farelerde yüksek olduğu bulunmuştur. Oksidan ve antioksidan mekanizmaları arasındaki dengesizliğin nöronal hasarı desteklediği ileri sürülmüştür (32). Antioksidanların ALS'deki yararı, transgenik SOD1 mutant farelerin ve hücre kültürlerinde $\mathrm{E}$ vitamini tedavisi ile gösterilmiştir. Andreassen ve ark., (2000) artmış mitokondriyal antioksidan aktivitenin, mutant SOD1 arac1l motor nöron dejenerasyonunu önleyebileceğini önermektedir. $\mathrm{Bu}, \quad \mathrm{ALS}$ hastalığının başlamasını ve ilerlemesini önlemek için etkili bir yaklaşım sağlayabilir (33).

\section{Huntington Hastalığı}

Huntington hastalığ $(\mathrm{HH})$ beyinde striatum'un yavaş yavaş atrofiye uğradığ kalıtsal bir hastalıktır. Yıllar sonra HH olan birisi kontrol edilemeyen hareketler, davranışsal bozukluklar ve zihinsel yıkım yaşayabilir. $\mathrm{HH}$, her iki cinsiyeti eşit etkileyen otozomal dominant bir bozukluktur. $\mathrm{Bu}$ kusurlu gene sahip herkeste hastalık belirtileri gelişir. Dünya çapında 100.000 de 5-10 kişide $\mathrm{HH}$ olduğu tahmin edilmektedir. HH, tipik olarak orta yaşta başlayan nörodejeneratif bir hastalıktır ve genetik kusuru, huntingtin proteinini (HTT) kodlayan IT-15 geninin ilk ekzonu içinde kararsız bir CAG trinükleotit 
tekrarı olarak tanımlanmıştır (20). Mutant HTT'nin konformasyonel değişikliklerinin diğer proteinlerle etkileşime yol açtığı, dolayısıyla transdüksiyon ve hücre içi iletişimin katılımını değiştirdiği varsayılmaktadır. $\mathrm{Bu}$ anormal protein, ubikitin ile konjüge edilmiş parçalara ayrılır; bu da nöron içi nükleer inklüzyonlar oluşturur. $\mathrm{Bu}$ intranükleer agregatlar; transkripsiyonel düzensizlik, proteazom bozukluğu, mitokondriyal bozukluk, serbest radikal hasarı ve eksitotoksisiteye varan toksik etkiler gösterir. Enerji metabolizmalarındaki hataların, serbest radikal kaynaklı oksidatif stresin ve eksitotoksisitenin etkileşimleri $\mathrm{HH}$ patogenezine ve diğer nörodejeneratif hastalıklara neden olduğu yaygın olarak kabul edilmektedir (34). Eksitotoksisite yoluyla, ister birincil ister ikincil olarak, kusurlu bir mitokondriyal enerji üretim sistemi, ilerleyici nöron ölümüne yol açar. Mitokondriyal toksinleri kullanan hayvan çalışmalarında oksidatif stres ve eksitotoksisite arasındaki etkileşimler vurgulanmıştır (35). $\mathrm{HH}$, glutamat veya kinolinik asit gibi uyarıcı amino asitlerin toksik etkilerinden dolayı beynin belirli bölgelerindeki nöronların kaybı ile karakterizedir. HH'de yağ asitlerinin artmış peroksidasyonu ilk kez Tellez-Nagel ve arkadaşları (1973) tarafından rapor edilmiştir. Genel olarak, beyin hücreleri artan glutamik asit veya diğer uyarıcı vericilere yanıt olarak nitrik oksit salar. Sonunda nitrik oksit lipit peroksidasyonu ve hücresel hasara girer (36).

\section{Tardif Diskinezi}

Tardif Diskinezi (TD), hareketle ilişkili nörolojik bozukluklardan biridir. Bu hastalık, monoamin oksidazların aktivitesi yoluyla oluşan hidrojen peroksitin yanı sıra dopamin kininlerin artan oluşumundan kaynaklanır. Horrobin ve ark., (1989) serbest radikallerin TD hastalarında yăg asitlerine zarar verebileceğini düşünmüşlerdir (37). Lohr ve ark., (2003) TD'li hastalarda, kontrol hastalarına kıyasla artmış lipit peroksidasyonunu bildirmişlerdir. Artan serbest radikaller, TD ile sonuçlanabilecek motor yolaklarda ve bazal ganglionlarda hasara neden olur (38). Beyin türevi nörotrofik faktörü (BDNF), beyinde ve periferde bulunan bir büyüme faktörüdür.
Nöron gelişimi, canlılığı ve işlevlerin sürdürülmesinde önemli rol oynamaktadır. Haloperidol kullanılarak TD geliştirilen fare deneylerinde, farelerin prefrontal korteks, striatum, substantia nigra ve globus pallidusunda BDNF düzeylerinde azalma olduğu gözlemlenmiş, mevcut azalmanın serbest radikallerde artışa ve oksidatif strese yol açtı̆̆ düşünülmüştür (39). Haloperidol kullanımı sonrası artmış lipid peroksidasyonu ve nitrit seviyelerindeki yükselmenin, oksidatif strese neden olduğu, antioksidan ajan kullanımı ile bu stresin azalmasına bağlı TD belirtilerinde azalma olduğu gösterilmiştir (40).

\section{Spinal Musküler Atrofi}

Spinal musküler atrofi (SMA), ikinci motor nöronların kalıtımsal bir hastalığıdır. Otozomal resesif nöromusküler hastalıklar arasında en sık görülen SMA'nın canlı doğumlarda ortaya çıkma olasıllığı kabaca 10,000 'de bir, taşıyıcılık sıklığı ise 50 'de birdir. Kollarda ve bacaklarda güçsüzlük ve atrofiyle seyreden bu hastalığın en ağır şeklinde solunum da etkilenir. SMA'ya benzer patolojik özellikleri olan ALS hastalarının ailesel alt grubunda süperoksit dismutaz (SOD1) mutasyonlarının saptanmas1, SMA patogenezinde oksidatif stres hipotezini doğurmuştur (41). Motor sinir hücrelerinin bir mutasyon nedeniyle SMN (Survival of Motor Neuron) proteinini yeterli miktarda üretmemesi sonucunda SMA ortaya çıkar. Ayrica antioksidan savunmada kilit enzimlerden olan SOD1 mutasyonu taşıyan farelerle yapılan bir araştırmada; normalde yaşayamayan bu farelerin SMN proteini fazla miktarda ifade ettirildiğinde yaşayabilir hale gelmeleri, SMA'nın altta yatan bir oksidatif stresle ilintili olabileceğini düşündürmüştür. 2004 yılında yapılan bir çalışmada SMA hastalarının beyin kesitlerinde glutamatın eksitotoksisitesine bağlı nöronal hasar izlenmiştir (42). Ayrıca yakın dönemde gerçekleştirilen bir başka araştırmada da immünohistokimya tekniğiyle SMA hastalarının otopsi materyalleri incelenmiş; sonuçta oksidatif hasarla uyumlu bulgular gözlenmiştir (43). Bunların dışında SMN proteininin hücre içinde antioksidan savunma mekanizmasında rolü olabileceğine dair 
yayınlar da mevcuttur. Sağlıklı bireylerde hücre strese girdiğinde, sitoplazmada strese karşı koruyucu stres granülleri oluşmaktadır. Stres durumunda yeni protein sentezi durdurulur, sitoplazmadaki serbest mRNA'lar ise bu granül yapilarında toplanır. RNA metabolizmasında görevli olan SMN'nin bu

\section{KAYNAKLAR}

1. Shichiri M. The role of lipid peroxidation in neurological disorders. J Clin Biochem and Nutrition 2014; 54:151-60.

2. Lan AP, Chen J, Chai ZF, et al. The neurotoxicity of iron, copper and cobalt in Parkinson's disease through ROSmediated mechanisms. Biometals 2016; 29:665-678.

3. Kavas GÖ. Serbest Radikaller ve Organizma Üzerine Etkileri. Türkiye Klinikleri 1989; 9:1-8.

4. Gaschler MM, Stockwell BR. Lipid peroxidation in cell death. Biochemical and Biophysical Research Communications 2017; 482:419-25.

5. Pong K. Oxidative stress in neurodegenerative diseases: therapeutic implications for superoxide dismutase mimetics. Expert Opinion on Biological Therapy 2003; 3: 127-39.

6. Speciale SG. MPTP: Insights into parkinsonian neurodegeneration. Neurotoxicology and Teratology 2002; 24:607-20.

7. Poh Loh K, Hong Huang S, De Silva R, et al. Oxidative stress: apoptosis in neuronal injury. Current Alzheimer Research 2006; 3, 327-37.

8. Wang X, Michaelis EK. Selective neuronal vulnerability to oxidative stress in the brain. Frontiers in Aging Neuroscience 2010; 2:12-18.

9. Lin L, Huang QX, Yang SS, et al. Melatonin in Alzheimer's disease. Int $J$ Mol Sci 2013; 14:14575-593.

10.Ma T, Tan M-S, Yu J-T, et al. Resveratrol as a therapeutic agent for Alzheimer's disease. Biomed Res Int 2014; 3505-3516.

11.Erdem M, Akarsu S, Pan E, et al. Bipolar disorder and oxidative stress. Psychiatry and Behavioral Sci 2014; 4:70-77. granüllerin oluşumunda ana rolü oynadığ1 gösterilmiştir (44). Bütün bu bulguların 1Şı̆̆ında hücrede SMN yokluğunun bir oksidatif stres yanıtını tetikleyebileceği, sağlıklı ve hasta hücreler karşılaştırılarak bu yanıtın araştırılabileceği düşünülmüştür (45)..

12.Kraus RL, Pasieczny R, LariosaWillingham $\mathrm{K}$, et al. Antioxidant properties of minocycline: neuroprotection in an oxidative stress assay and direct radical-scavenging activity. Journal of Neurochemistry 2005; 94:819-27.

13.Kumar NS, Nisha N. Phytomedicines as potential inhibitors of $\beta$ amyloid aggregation: significance to Alzheimer's disease. Chin J Nat Med 2014; 12:801-18.

14.Xiong Z, Hongmei Z, Lu S, et al. Curcumin mediates presenilin-1 activity to reduce betaamyloid production in a model of Alzheimer's Disease. Pharmacol Rep 2011; 63:1101-1108.

15.Ji S, Li S, Zhao X, et al. Protective role of phenylethanoid glycosides, Torenoside B and Savatiside A, in Alzheimer's disease. Exp Ther Med 2019; 17:3755-67.

16.Hur J, Pak SC, Koo BS, et al. Borneol alleviates oxidative stress via upregulation of Nrf2 and Bcl-2 in SH-SY5Y cells. Pharm Biol 2013; 51:30-5.

17.Zhang $\mathrm{X}$, Wang $\mathrm{X}$, $\mathrm{Hu} \mathrm{X}$, et al. Neuroprotective effects of a Rhodiola crenulata extract on amyloid- $\beta$ peptides $(A \beta(1-42))$-induced cognitive deficits in rat models of Alzheimer's disease. Phytomedicine 2019; 57:331-38.

18. Kantar Gok D, Hidisoglu E, Ocak GA, et al. Protective role of rosmarinic acid on amyloid beta 42-induced echoic memory decline: Implication of oxidative stress and cholinergic impairment. Neurochem Int, 2018; 118: 1-13.

19. Khodadadian A, Hemmati-Dinarvand M, Kalantarycharvadeh A, et al. Candidate biomarkers for Parkinson's disease. Biomedicine and Pharmacotherapy 2018; 104:699-704.

20.Rao AV, Balachandran B. Role of oxidative stress and antioxidants in 
neurodegenerative diseases. Nutritional neuroscience 2002; 5:291-309.

21.Hwang O. Role of Oxidative Stress in Parkinson's Disease. Experimental Neurobiology 2013; 22:11-19.

22.Johnson WM, Wilson-Delfosse AL, Mieyal JJ. Dysregulation of glutathione homeostasis in neurodegenerative diseases. Nutrients 2012; 4:1399-40.

23.Aoyama K, Nakaki T. Impaired glutathione synthesis in neurodegeneration. Int J Mol Sci 2013; 14:21021-21044.

24.Baillet A, Chanteperdrix V, Trocmé C, et al. The role of oxidative stress in amyotrophic lateral sclerosis and Parkinson's disease. Neurochem Research 2010; 35:1530-37.

25.Dexter DT, Carter CJ, Wells FR, et al.. Basal lipid peroxidation in substantia nigra is increased in Parkinson's disease. $J$ Neurochem 1989; 52:381-389.

26. Sayre LM, Perry G, Harris PLR, et al. In situ oxidative catalysis by neurofibrillary tangles and senile plaques in Alzheimer's disease: a central role for bound transition metals. J Neurochem 2000; 74:270-279.

27.Lewis SJG, Caldwell MA, Barker RA. Modern therapeutic approaches in Parkinson's disease. Expert Reviews in Molecular Medicine 2003; 5:1-20.

28. Sanyal J, Bandyopadhyay SK, Banerjee TK, et al. Plasma levels of lipid peroxides in patients with Parkinson's disease. Eur Rev Med Pharmacol Sci 2009; 13:129-132.

29. De Farias CC, Maes M, Bonifácio KL, et al. Highly specific changes in antioxidant levels and lipid peroxidation in Parkinson's disease and its progression: Disease and staging biomarkers and new drug targets. Neuroscience Letters 2016; 617:66-71.

30. Barber SC, Shaw PJ. Oxidative stress in ALS: key role in motor neuron injury and therapeutic target. Free Radical Biology and Medicine 2010; 48:629-41.

31.Barber SC, Mead RJ, Shaw PJ. Oxidative stress in ALS: a mechanism of neurodegeneration and a therapeutic target. Biochimica et Biophysica Acta (BBA)-Molecular Basis of Disease 2006, 1762:1051-1067.

32.Liu R, Li B, Flanagan SW, et al. Increased mitochondrial antioxidative activity or decreased oxygen free radical propagation prevent mutant SOD1-mediated motor neuron cell death and increase amyotrophic lateral sclerosis-like transgenic mouse survival. $J$ Neurochem 2002; 80:488-500.

33. Andreassen OA, Ferrante R, Klivenyi P, et al. Partial deficiency of manganese superoxide dismutase exacerbates a transgenic mouse model of amyotophic lateral sclerosis. Annals of Neurology 2000; 47:447-455.

34. Sorolla MA, Reverter-Branchat G, Tamarit $\mathrm{J}$, et al. Proteomic and oxidative stress analysis in human brain samples of Huntington disease. Free Radical Biology and Medicine 2008; 45:667-678.

35.Browne SE, Ferrante RJ, Beal MF. Oxidative stress in Huntington's disease. Brain pathology 1999; 9:147-163.

36. Tellez-Nagel I, Johnson AB, Terry RD. Ultrastrucutural and histochemical study of cerebral biopsies in Huntington's chorea. In: Barbeau A, Chase TN, Paulson GW, editors. Advances in Neurology, Raven Press, New York, 1973. p. 387-98.

37.Horrobin DF, Manku MS, Morse-Fisher N, et al. Essential fatty acids in plasma phospholipids in schizophrenics. Biological Psychiatry 1989; 25:562-68.

38.Lohr JB, Kuczenski R, Niculescu AB. Oxidative mechanisms and tardive dyskinesia. CNS drugs 2003; 17:47-62.

39. Cho $\mathrm{CH}$, Lee HJ. Oxidative stress and tardive dyskinesia: pharmacogenetic evidence. Progress in NeuroPsychopharmacology and Biological Psychiatry 2013; 46:207-213.

40.De Araújo DP, Camboim TGM, Silva APM, et al. Behavioral and neurochemical effects of alpha lipoic acid associated with omega-3 in tardive dyskinesia induced by chronic haloperidol in rats. Canadian journal of physiology and pharmacology 2017; 95:837-843.

41.Zou T, Ilangovan R, Yu F, et al. SMN protects cells against mutant SOD1 toxicity by increasing chaperone activity. Biochem Biophys Res Commun 2007; 364:850-55.

42.Hayashi M, Araki S, Arai N, et al. Oxidative stress and disturbed glutamate 
transport in spinal muscular atrophy. Brain Dev 2002; 24:770-775.

43. Hayashi M. Oxidative stress in developmental brain disorders. Neuropathology 2009, 29:1-8.

44.Hua Y, Zhou J. Rpp20 interacts with SMN and is re-distributed into SMN granules in response to stress. Biochem Biophys Res Commun 2004; 314:268-76.

45. Hua Y, Zhou J. Survival motor neuron protein facilitates assembly of stress granules. FEBS Lett 2004; 572:69-74. 